\title{
Tropolone as a Root Growth-Inhibitor Produced by a Plant Pathogenic Pseudomonas sp. Causing Seedling Blight of Rice
}

\author{
Koji Azegami*, Koushi Nishiyama*, Yasumasa Watanabe*, Takayuki Suzuki*, \\ Mitsuru Yoshida*, Kazuo Nose* and Shozo TodA**
}

Key Words : tropolone, Pseudomonas, seedling blight, rice.

Tropolone was isolated from the shake-cultured medium of a plant pathogenic Pseudomonas sp., and was found to act as a root growth-inhibitor. It can be used for the detection and the identification of the pathogen.

Recently, seedling blight of rice grown in nursery boxes has occurred annually in the northeastern part of Chiba prefecture, Japan. Root growth of diseased seedlings is seriously impaired and the seedlings easily tumble over, hence the symptoms are referred to as "korobi-nae (seedling tumbling)". When the growth of the affected seedlings exceeds several centimeters, chlorosis occurs at the basal parts of the leaves. Then, the seedlings wither and become brown, but never rot.

The Omigawa isolate of Pseudomonas sp. named after the town from which it was first isolated, was shown to be the causal agent of the disease, and was related to $P$. gladioli pv. gladioli and $P$. glumae based on bacteriological characteristics ${ }^{1}$. However, these three pseudomonads were different from one another pathologically, symptomatologically, serologically, and in some of their bacteriological characteristics. P. gladioli pv. gladioli, which is pathogenic to gladiolus, did not induce any disease to rice seedlings by seed soaking inoculation. Although the other two pseudomonads were pathogenic to rice seedlings, the symptoms were different, i. e. the seedlings infected with the Omigawa isolate withered, became brown, dried, and never rotted while those infected with $P$. glumae became brown and easily rotted. $P$. glumae is known to be serologically homogeneous and have a common antigen with $P$. gladioli pv. gladioli ${ }^{1)}$ The Omigawa isolate reacted with neither antisera of $P$. glumae nor $P$. gladioli pv. gladioli.

Shake-cultured medium of the Omigawa isolate inhibited root growth of rice, and contained an inhibitory agent, which was purified. The bacterium was incubated at $28 \mathrm{C}$ in the dark for 4 days in modified Ayers, Rupp and Johnson's medium $\left(\mathrm{NH}_{4} \mathrm{H}_{2} \mathrm{PO}_{4} 1.0 \mathrm{~g}, \mathrm{KCl}\right.$ $0.2 \mathrm{~g}, \mathrm{MgSO}_{4} \cdot 7 \mathrm{H}_{2} \mathrm{O} 0.2 \mathrm{~g}$, distilled water 1 liter, $\mathrm{pH} 7.2 \sim 7.4$ ) supplemented with $10 \mathrm{~g}$ glucose. The inhibition activity was recognized in the ethyl ether extract of the cultured medium (6 liter, $\mathrm{pH} 3.5 \sim 3.6$ ) (Table 1). The solvent was evaporated and the residue

\footnotetext{
* National Institute of Agro-Environmental Sciences, Yatabe, Tsukuba, Ibaraki 305, Japan 農業環境技術研究所

** Faculty of Agriculture, The University of Tokyo, Bunkyo-ku, Tokyo 113, Japan 東京大学農学部

1) Azegami, K., Nishiyama, K. and Watanabe, Y. (1983). Ann. Phytopath. Soc. Japan $49: 411$.
} 
Table 1. Inhibition activity of crude ether extract from shake-cultured medium, sublimated crystal and authentic tropolone on the growth of rice

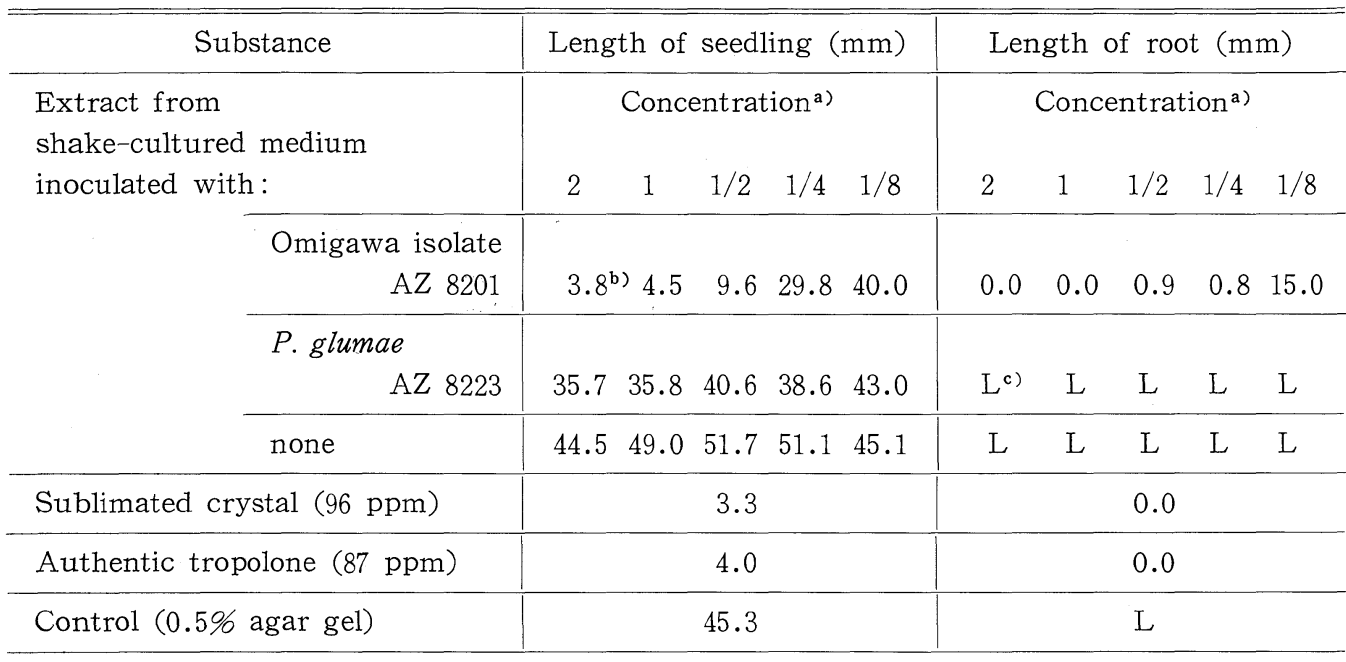

a) Concentration $2,1,1 / 2,1 / 4$ and $1 / 8$ indicates that $10 \mathrm{ml}$ of $0.5 \%$ agar gel contained the extract from $20,10,5,2.5$, and $1.25 \mathrm{ml}$ of the shake-cultured medium respectively. The medium was adjusted to $\mathrm{pH} 3.5 \sim 3.6$ before extraction.

b) Means of 10 seedlings. Five rice seeds were sown on the agar gel in a small glass tube $(2.6 \times 6.0 \mathrm{~cm})$. The length of the above-ground parts and the roots was measured 7 days after sowing and incubation at $30 \mathrm{C}$ in the dark.

c) L: Longer than $20 \mathrm{~mm}$.

was reextracted with acetone. After evaporation, the extract was fractionated by ethyl ether according to standard methods and the activity was detected in the acidic fraction. This fraction was applied on a silica gel column $(1.5 \times 25 \mathrm{~cm})$ and the active material was eluted with acetone-benzene $1: 1(\mathrm{v} / \mathrm{v})$. Colorless, transparent needle and prismatic crystals which showed the activity were sublimated at room temperature from the eluate. UV and MS analyses were performed on the sublimate, and the data suggested that the substance was tropolone ${ }^{2,3)}$. The comparison of UV spectrum $\left(\lambda_{\max }\right.$ : $320,353,370 \mathrm{~nm}$, in ethyl acetate), MS spectrum $\left(\mathrm{m} / \mathrm{e}: 122\left(\mathrm{M}^{+}\right), 94\right)$, and the activity (Table 1) of the sublimate with those of authentic tropolone (Tokyo Chemical Industry Co., Ltd. EP grade) confirmed that the sublimate consisted of tropolone (2-hydroxy-2, 4, 6-cycloheptatriene-1-one).

Tropolone is a non-benzenoid aromatic compound with a seven-membered ring, and tropolone derivatives have already been isolated from the wood of several trees (hinokitiol, thujaplicins, nootkatin), Penicillium sp. (stipitatic acid), galls of Quercus sp. (purpurogallin) and Liliaceae (colchicine). Tropolone is known to have an antibacterial activity $^{4}$. Lindberg et al. ${ }^{5}$ were able to detect tropolone in the cultured medium of

2) Doering, W. von E. and Knox, L.H. (1951). J. Am. Chem. Soc. $73: 828-838$. 3) Stenhagen, E., Abrahamsson, S. and McLafferty, F. W. eds. (1974): Registry of Mass Spectral Data, Vol. 1. John Wiley and Sons, New York. p. 190. 4) Trust, T. J. (1975). Antimicrob. Agents Chemother. $7: 500-506$. 5) Lindberg, G. D., Larkin, J. M. and Whaley, H. A. (1980). J. Nat. Prod. 43:592-594. 
the Pseudomonas sp. which was found among the colonies of fungi isolated from Bermuda grass. Lindberg6) ${ }^{6}$ reported that tropolone was also lethal to many fungi, although he did not mention the existence of the plant pathogenicity of the bacterial isolate, which was different from the Omigawa isolate in ten bacteriological characteristics.

Tropolone shows a strong UV absorption at $320 \mathrm{~nm}$ in ethyl acetate. When only a fragment of a diseased seedling which had been inoculated with a small amount of this bacterium was soaked in ethyl acetate in a quartz cell, the peak could be detected. Thus it is concluded that tropolone is produced by the bacterium in the medium as well as in rice plant, and is responsible for the symptoms of seedling tumbling without rotting. Tropolone was not detected in the shake-cultured media of the pathogenic Pseudomonas spp. ( $P$. gladioli pv. gladioli, $P$. glumae, $P$. avenae, $P$. solanacearum) by UV analysis. Thus UV screening should be helpful in the detection and identification of the Omigawa isolate which is presently under way in the laboratory.

The authors are grateful to Dr. K. Ohata, Head of the Division of Microbiology, National Institute of Agro-Environmental Sciences, for his helpful advice in the preparation of the manuscript.

\section{和 文 摘 要}

畔上耕児・西山幸司・渡辺康正・鈴木隆之・吉田 充・能勢和夫・戸田昭三 : イネ交亩枯症の病原細菌が産 生する発根抑制物質トロポロン

千葉県では数年来，箱育苗のイネ苖立枯症が発生している。罹病苗の根の生育はきわめて悪く，そのために 育苗箱に播かれたイネすみは発芽しても倒れやすい。この症状を起てす Pseudomonas 属菌の培養ろ液からト ロポロンが単離された。この物質は痽病イネ苗からも検出され，発根や根の生育，ひいては地上部の生育を抑 制していることがわかった。P. glumae による苗腐敗症とは異なり，罹病苗は褐変しても腐敗しない。それは この物質の抗菌作用によるものと考えられる。トロポロンは $320 \mathrm{~nm}$ に強い吸収ピークを持ち, 罹病組織の一 片を酢酸エチルなどの有機溶媒に浸漬するだけで抽出可能であり，また近縁の病原菌からは検出されないの で，篗病組織より抽出した試料の紫外分光分析はこの病原菌の検出や同定に有効であると考えられる。

(Received February 25, 1985)

6) Lindberg, G.D. (1981). Plant Disease $65: 680-683$. 